\title{
VENTILatOry strategies in patients with severe traumatic brain injury: the VENTILO Survey of the European Society of Intensive Care Medicine (ESICM)
}

Edoardo Picetti ${ }^{*}$, Paolo Pelosi ${ }^{2,3}$, Fabio Silvio Taccone ${ }^{4}$, Giuseppe Citerio ${ }^{5}$, Jordi Mancebo ${ }^{6}$, Chiara Robba $^{2}$ and on the behalf of the ESICM NIC/ARF sections

\begin{abstract}
Background: Severe traumatic brain injury (TBI) patients often develop acute respiratory failure. Optimal ventilator strategies in this setting are not well established. We performed an international survey to investigate the practice in the ventilatory management of TBI patients with and without respiratory failure.

Methods: An electronic questionnaire, including 38 items and 3 different clinical scenarios [arterial partial pressure of oxygen $\left(\mathrm{PaO}_{2}\right)$ /inspired fraction of oxygen $\left(\mathrm{FiO}_{2}\right)>300$ (scenario 1), 150-300 (scenario 2), <150 (scenario 3)], was available on the European Society of Intensive Care Medicine (ESICM) website between November 2018 and March 2019. The survey was endorsed by ESICM.

Results: There were 687 respondents [472 (69\%) from Europe], mainly intensivists [328 (48\%)] and anesthesiologists [206 (30\%)]. A standard protocol for mechanical ventilation in TBI patients was utilized by 277 (40\%) respondents and a specific weaning protocol by 198 (30\%). The most common tidal volume (TV) applied was 6-8 $\mathrm{ml} / \mathrm{kg}$ of predicted body weight (PBW) in scenarios 1-2 (72\% $\mathrm{PaO}_{2} / \mathrm{FIO}_{2}>300$ and $61 \% \mathrm{PaO}_{2} / \mathrm{FiO}_{2}$ 150-300) and 4-6 ml/kg/ PBW in scenario $3\left(53 \% \mathrm{PaO}_{2} / \mathrm{FiO}_{2}<150\right)$. The most common level of highest positive end-expiratory pressure (PEEP) used was $15 \mathrm{cmH}_{2} \mathrm{O}$ in patients with a $\mathrm{PaO}_{2} / \mathrm{FiO}_{2} \leq 300$ without intracranial hypertension $\left(41 \%\right.$ if $\mathrm{PaO}_{2} / \mathrm{FiO}_{2}$ 150-300 and $50 \%$ if $\mathrm{PaO}_{2} / \mathrm{FiO}_{2}<150$ ) and $10 \mathrm{cmH}_{2} \mathrm{O}$ in patients with intracranial hypertension $\left(32 \%\right.$ if $\mathrm{PaO}_{2} / \mathrm{FiO}_{2}$ $150-300$ and $33 \%$ if $\mathrm{PaO}_{2} / \mathrm{FiO}_{2}<150$ ). Regardless of the presence of intracranial hypertension, the most common carbon dioxide target remained $36-40 \mathrm{mmHg}$ whereas the most common $\mathrm{PaO}_{2}$ target was $81-100 \mathrm{mmHg}$ in all the 3 scenarios. The most frequent rescue strategies utilized in case of refractory respiratory failure despite conventional ventilator settings were neuromuscular blocking agents [406 (88\%)], recruitment manoeuvres [319 (69\%)] and prone position [292 (63\%)].
\end{abstract}

Conclusions: Ventilatory management, targets and practice of adult severe TBI patients with and without respiratory failure are widely different among centres. These findings may be helpful to define future investigations in this topic.

Keywords: Traumatic brain injury, Mechanical ventilation, Respiratory failure

\footnotetext{
* Correspondence: edoardopicetti@hotmail.com

${ }^{1}$ Department of Anesthesia and Intensive Care, Parma University Hospital, Via Gramsci 14, 43100 Parma, Italy

Full list of author information is available at the end of the article
}

\section{$\triangle B M C$}

(c) The Author(s). 2020 Open Access This article is licensed under a Creative Commons Attribution 4.0 International License, which permits use, sharing, adaptation, distribution and reproduction in any medium or format, as long as you give appropriate credit to the original author(s) and the source, provide a link to the Creative Commons licence, and indicate if changes were made. The images or other third party material in this article are included in the article's Creative Commons licence, unless indicated otherwise in a credit line to the material. If material is not included in the article's Creative Commons licence and your intended use is not permitted by statutory regulation or exceeds the permitted use, you will need to obtain permission directly from the copyright holder. To view a copy of this licence, visit http://creativecommons.org/licenses/by/4.0/ The Creative Commons Public Domain Dedication waiver (http://creativecommons.org/publicdomain/zero/1.0/) applies to the data made available in this article, unless otherwise stated in a credit line to the data. 


\section{Background}

Traumatic brain injury (TBI) is a worldwide health problem with elevated rate of mortality and disability [1]. Brain-injured patients with altered consciousness frequently require intubation and invasive mechanical ventilation to protect the airways from aspiration and to prevent harmful secondary insults, such as hypoxemia [generally defined as an arterial partial pressure of oxygen $\left(\mathrm{PaO}_{2}\right)<60 \mathrm{mmHg}$ ] and hypercapnia [generally defined as an arterial partial pressure of carbon dioxide $\left(\mathrm{PaCO}_{2}\right)>45 \mathrm{mmHg}$ ] [2]. TBI patients may develop severe respiratory failure and acute respiratory distress syndrome (ARDS) during intensive care unit (ICU) stay $[3,4]$. Lung-protective ventilation strategies, with low tidal volumes (TVs) and moderate-to-high positive endexpiratory pressure (PEEP), are associated with improved outcomes in ARDS and non-ARDS patients [5, 6] and are characterized by "low ranges" oxygenation targets and permissive hypercapnia [7, 8]. This approach, considering its potential adverse cerebrovascular effects, is difficult to apply in TBI patients, regardless of the presence of intracranial hypertension $[2,9,10]$. Traditionally, in TBI patients, low PEEP and high TVs are generally applied for tight $\mathrm{CO}_{2}$ control [5]; however, recent evidence suggests that, even in TBI patients, the use of high TVs is associated with the development of acute lung injury $[9,11]$. As such, brain-injured patients have been excluded from the major trials exploring the effect of lung-protective ventilation strategies in ARDS [12, 13], and consequently optimal ventilatory strategies have not been established yet in this setting $[14,15]$. We therefore performed an international survey with the aim to investigate the practice in the respiratory management of TBI patients, with and without respiratory failure.

\section{Methods}

This international survey was endorsed by the European Society of Intensive Care Medicine (ESICM) and promoted by the Neuro-intensive Care (NIC) and the Acute Respiratory Failure (ARF) sections. An electronic questionnaire, including 38 items and 3 different clinical scenarios $\left[\mathrm{PaO}_{2} /\right.$ inspired fraction of oxygen $\left(\mathrm{FiO}_{2}\right)\left(\mathrm{PaO}_{2} / \mathrm{FiO}_{2}\right)>300,150-$ $300,<150$ ], was available on the ESICM website between November 2018 and March 2019 (Appendix 1 in the Additional file 1). The survey was developed by two investigators (E.P. and C.R.) following a non-systematic review of the literature on respiratory management in TBI patients. The questionnaire was created considering some issues around this topic, such as low levels of evidence, lack of good quality studies and controversial results from observational trials. The survey was designed to identify (a) characteristics of the participants demographics, type of hospital/specialty and available neuromonitoring tools (questions 1 to 10), (b) protocols for mechanical ventilation and weaning (questions
11, 12 and 14) and (c) respiratory management strategies (questions 13 and 15 to 38). The target audience was ESICM members who had agreed to participate in ESICM surveys at the time of their membership registration and who treat patients with TBI in their clinical practice. The investigators invited the target participants to involve more respondents locally. Participants did not receive compensation for their participation in the survey, which was distributed via the ESICM office, thus protecting data confidentiality and anonymity. The survey was registered within the ESICM Survey portfolio and no ethical approval was required. The questionnaire was not specifically tested in a pilot cohort of potential respondents but underwent a peer-review process within the ESICM Research Committee.

\section{Data analyses and statistical methods}

Data from the questionnaire were exported as a commaseparated value report from the Surveymonkey ${ }^{\circ}$ software package and subsequently stored as an Excel file (Microsoft Corp, Redmond, WA). Descriptive statistics were computed for all study variables. The results are presented as numbers and percentage. Two main subdivisions were considered in the population: one based on geographic area (Europe vs. Others), one based on ICU characteristics [specialized neuro-ICU (NICU) vs. nonspecialized NICU]. Results for the population as a whole and for the sub-group subdivision are reported. Differences between groups (e.g. specialized NICU vs. nonspecialized NICU, Europe vs. Others) were assessed using a chi-squared test for binary variables in $2 \times 2$ or $\mathrm{r} \times \mathrm{c}$ contingency tables. Cells with fewer than 5 cases were grouped with other cells taking care that the new group was clinically appropriate. For the questions where more than one test was necessary (for example questions concerning rescue strategies), a Bonferroni correction for multiple comparisons was adopted. Stata software release 13.0 was used for the statistical analysis (StataCorp, 2013, Stata Statistical Software, Release 13; StataCorp LP, College Station, TX). $P<0.05$ was considered as statistically significant.

\section{Results}

The total number of respondents was 687 from 676 centres around the world [the number of respondents in relation to completed items is shown Table S1 in the Additional file 1). Most of the respondents $(n=472$ [69\%]) were from Europe. Italy was the country with the highest number of respondents $(n=86)$, followed by Sudan $(n=60)$, the USA $(n=47)$ and Brazil $(n=43)$ (Fig. 1). The majority of respondents were intensivists $(n=328[48 \%])$ and anesthesiologists $(n=206$ [30\%]) working in mixed general and NICUs $(n=278$ [41\%]). 


\section{Countries of Respondents}

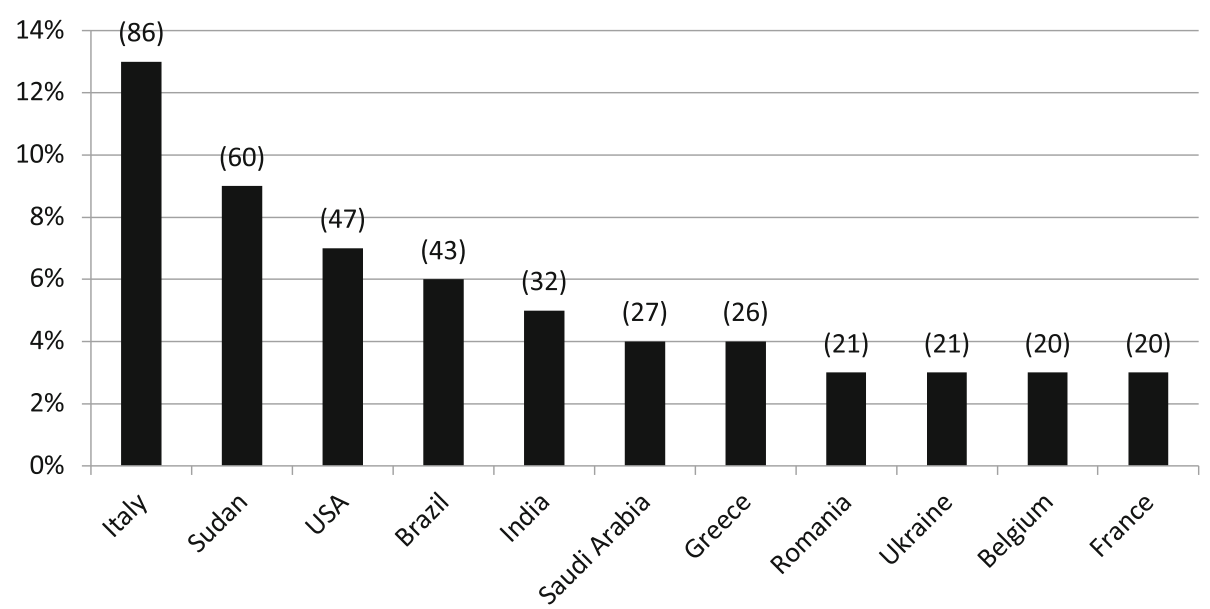

Fig. 1 Number of respondents per country. Only countries with a number of responses $>20$ have been included. Abbreviations: USA = United States of America. The number of respondents is shown in brackets

Baseline characteristics of the survey participants are shown in Table 1.

A standard protocol for mechanical ventilation in TBI patients was utilized by $277(40 \%)$ respondents and a specific weaning protocol by 198 (30\%). Automated ventilation modes were utilized by 331 (50\%) participants. A driving pressure $<15 \mathrm{cmH}_{2} \mathrm{O}$ and a plateau pressure $<$ $30 \mathrm{cmH}_{2} \mathrm{O}$ were utilized by most respondents [respectively $436(68 \%)$ and $616(95 \%)$ ].

Ventilator settings and respiratory targets utilized in the three clinical scenarios with different respiratory failure severity are reported in Table 2 . The most common TV applied was $6-8 \mathrm{ml} / \mathrm{kg} /$ predicted body weight (PBW) in case of $\mathrm{PaO}_{2} / \mathrm{FiO}_{2} \geq 150$ (72\% for $\mathrm{PaO}_{2} / \mathrm{FiO}_{2}>300$ and $61 \%$ for $\mathrm{PaO}_{2} / \mathrm{FiO}_{2} 150-300$ ) and $4-6 \mathrm{ml} / \mathrm{kg} / \mathrm{PBW}$ in case of $\mathrm{PaO}_{2} / \mathrm{FiO}_{2}<150$ (53\%). In patients without intracranial hypertension, the most utilized highest PEEP and $\mathrm{PaCO}_{2}$ targets in all 3 clinical scenarios were $15 \mathrm{cmH}_{2} \mathrm{O}$ (30\% for $\mathrm{PaO}_{2} / \mathrm{FiO}_{2}>300,41 \%$ for $\mathrm{PaO}_{2} /$ $\mathrm{FiO}_{2} 150-300$ and $50 \%$ for $\mathrm{PaO}_{2} / \mathrm{FiO}_{2}<150$ ) and 36-40 mmHg (51\% for $\mathrm{PaO}_{2} / \mathrm{FiO}_{2}>300,47 \%$ for $\mathrm{PaO}_{2} / \mathrm{FiO}_{2}$ 150-300 and $37 \%$ for $\mathrm{PaO}_{2} / \mathrm{FiO}_{2}<150$ ) respectively. In patients with intracranial hypertension, the most utilized highest PEEP was $5 \mathrm{cmH}_{2} \mathrm{O}$ in scenario 1 (27\%) and $10 \mathrm{cmH}_{2} \mathrm{O}$ in scenarios 2-3 (32\% for $\mathrm{PaO}_{2} / \mathrm{FiO}_{2} 150$ 300 and $33 \%$ for $\left.\mathrm{PaO}_{2} / \mathrm{FiO}_{2}<150\right)$ whereas the $\mathrm{PaCO}_{2}$ targets were $36-40 \mathrm{mmHg}$ in all 3 scenarios $(43 \%$ for $\mathrm{PaO}_{2} / \mathrm{FiO}_{2}>300,49 \%$ for $\mathrm{PaO}_{2} / \mathrm{FiO}_{2} 150-300$ and $47 \%$ for $\left.\mathrm{PaO}_{2} / \mathrm{FiO}_{2}<150\right)$. The most common $\mathrm{PaO}_{2}$ target was $81-100 \mathrm{mmHg}$ in all the 3 groups $\left(57 \%\right.$ for $\mathrm{PaO}_{2} /$ $\mathrm{FiO}_{2}>300,53 \%$ for $\mathrm{PaO}_{2} / \mathrm{FiO}_{2} 150-300$ and $45 \%$ for $\mathrm{PaO}_{2} / \mathrm{FiO}_{2}<150$ ).

The most common ventilator settings and respiratory targets in the 3 clinical scenarios are presented in Fig. 2.
The most frequent rescue strategies utilized in case of refractory respiratory failure, despite the application of a lung-protective ventilation strategy, were neuromuscular blocking agents (NMBAs) [406 (88\%)], followed by recruitment manoeuvres [319 (69\%)] and prone position [292 (63\%)] (Table 3).

Data regarding comparisons between European versus non-European respondents and non-specialized versus specialized NICUs are reported in Table S2 in the Additional file 1. European respondents, when compared to non-European, had (1) less frequently standardized protocols for mechanical ventilation and weaning, (2) higher $\mathrm{PaCO}_{2}$ targets, (3) a higher utilization of neuromonitoring to set $\mathrm{PaO}_{2}$ targets and (4) more frequent use of NMBAs as rescue strategy for refractory respiratory failure.

Respondents working in specialized NICUs, compared to those from non-specialized NICUs, had (1) a less frequent use of plateau pressure target $<30 \mathrm{cmH}_{2} \mathrm{O}$ and (2) higher $\mathrm{PaO}_{2}$ targets.

Data regarding available bedside neuromonitoring between non-specialized versus specialized NICUs are reported in Table S3 in the Additional file 1. Except for near-infrared spectroscopy (NIRS), specialized NICUs, compared to non-specialized NICUs, had more available bedside neuromonitoring tools.

\section{Discussion}

This international survey provides important information regarding the respiratory management of TBI patients admitted to ICU. The main results of our survey can be summarized as follows: (1) few respondents utilized specific protocols for mechanical ventilation and weaning in TBI, (2) low TVs with a $\mathrm{PaCO}_{2}$ target of 36- 
Table 1 Baseline characteristics of the overall population

\begin{tabular}{|c|c|}
\hline & Respondents $(n=687)$ \\
\hline \multicolumn{2}{|l|}{ Gender } \\
\hline Male & $452(66 \%)$ \\
\hline Female & $235(34 \%)$ \\
\hline \multicolumn{2}{|l|}{ Age (years) } \\
\hline$<35$ & $115(17 \%)$ \\
\hline $35-45$ & $282(41 \%)$ \\
\hline $45-65$ & $249(36 \%)$ \\
\hline$>65$ & $41(6 \%)$ \\
\hline \multicolumn{2}{|l|}{ Specialty } \\
\hline Intensive care medicine & $328(48 \%)$ \\
\hline Anesthesiology & $206(30 \%)$ \\
\hline Neurocritical care & $61(9 \%)$ \\
\hline Internal medicine & $35(5 \%)$ \\
\hline Others & $57(8 \%)$ \\
\hline \multicolumn{2}{|c|}{ Post-specialization experience in critical care (years) } \\
\hline $1-5$ & $180(26 \%)$ \\
\hline $6-10$ & $149(22 \%)$ \\
\hline$>10$ & $358(52 \%)$ \\
\hline \multicolumn{2}{|l|}{ Type of ICU } \\
\hline Mixed general and neurolCU & $278(41 \%)$ \\
\hline General ICU & $271(39 \%)$ \\
\hline Specialized neuroICU & $130(19 \%)$ \\
\hline Others & $8(1 \%)$ \\
\hline \multicolumn{2}{|l|}{ ICU beds } \\
\hline$<5$ & $111(16 \%)$ \\
\hline $6-10$ & 196 (29\%) \\
\hline $11-15$ & $133(19 \%)$ \\
\hline$>15$ & 247 (36\%) \\
\hline \multicolumn{2}{|l|}{ Affiliation } \\
\hline University & $501(73 \%)$ \\
\hline Non-university & $186(27 \%)$ \\
\hline \multicolumn{2}{|c|}{ Available bedside neuromonitoring } \\
\hline ICP & $546(80 \%)$ \\
\hline $\mathrm{PbtO} 2$ & $149(22 \%)$ \\
\hline NIRS & $215(31 \%)$ \\
\hline TCD & $442(64 \%)$ \\
\hline Cerebral microdialysis & $50(7 \%)$ \\
\hline Intermittent EEG & $522(76 \%)$ \\
\hline Continuous EEG & $262(38 \%)$ \\
\hline Pupillometer & $85(12 \%)$ \\
\hline SjVO2 & 209 (30\%) \\
\hline
\end{tabular}

Abbreviations: ICU intensive care unit, ICP intracranial pressure, $\mathrm{PbtO} 2$ brain tissue oxygen tension, NIRS near infrared spectroscopy, TCD transcranial Doppler, EEG electroencephalography, SjVO2 jugular venous oxygen saturation
$40 \mathrm{mmHg}$ are frequently utilized, (3) lower levels of PEEP are employed in case with intracranial hypertension, (4) NMBAs are the most common rescue strategy in cases of refractory respiratory failure and finally (5) a great variability in practices exists.

To our knowledge, this is the largest survey published so far regarding ventilator strategies in head injured patients. Respondents are coming from different countries around the world, and therefore, our results are representative of the worldwide current clinical practice in this field.

\section{Ventilator settings and respiratory targets in TBI}

Lung-protective ventilation strategies have shown to have a beneficial impact on outcome in patients with and without ARDS [15]. In particular, low TVs are a fundamental component of lung-protective ventilation and their utilization is associated with a reduced mortality in ARDS patients [5, 6]. Although low TVs can potentially cause hypercapnia and consequent intracranial cerebral vessel vasodilation, the use of high TVs in TBI patients $(>9 \mathrm{ml} / \mathrm{kg} / \mathrm{PBW})$, with normal lung at ICU admission, is associated with the development of ARDS [11]. Prospective studies regarding low TVs are lacking in TBI and the optimal TV value still need to be established in this setting. Surprisingly, the majority of our respondents declared that they utilize low TVs, even in specialized NICUs, thus suggesting that the concept of lung-protective ventilation is gaining interest even in this group of patients.

The application of PEEP, as well as low TVs, is an important component of lung-protective ventilation [7]. PEEP reduces atelectasis and improves $\mathrm{PaO}_{2}$ and lung compliance [7]. Traditionally, low PEEP levels $(\leq 5$ $\mathrm{mmHg}$ ) have been utilized in acute brain injury patients admitted to ICU [5], because of the potential risks on cerebral circulation and intracranial pressure (ICP); in particular, the effect of PEEP on ICP seems to be related to both hemodynamic factors and respiratory system compliance $[9,10]$. Elevated PEEP levels may reduce systemic venous return, mean arterial pressure and consequently cerebral perfusion pressure (CPP) with detrimental consequences on cerebral blood flow (CBF), mainly in cases of altered cerebral autoregulation [16]. On the other hand, respiratory system compliance influences the effect of PEEP on ICP and brain circulation [17-19]: in patients with low compliance, a PEEP increase (up to $10-12 \mathrm{cmH}_{2} \mathrm{O}$ ) is not associated with ICP increase; in contrast, in patients with normal compliance, PEEP induces lung overdistension, reduction in cerebral venous return and ICP increases. We found that most of our respondents utilize lower PEEP levels in case of intracranial hypertension, thus suggesting that there is still concern regarding the cerebrovascular 


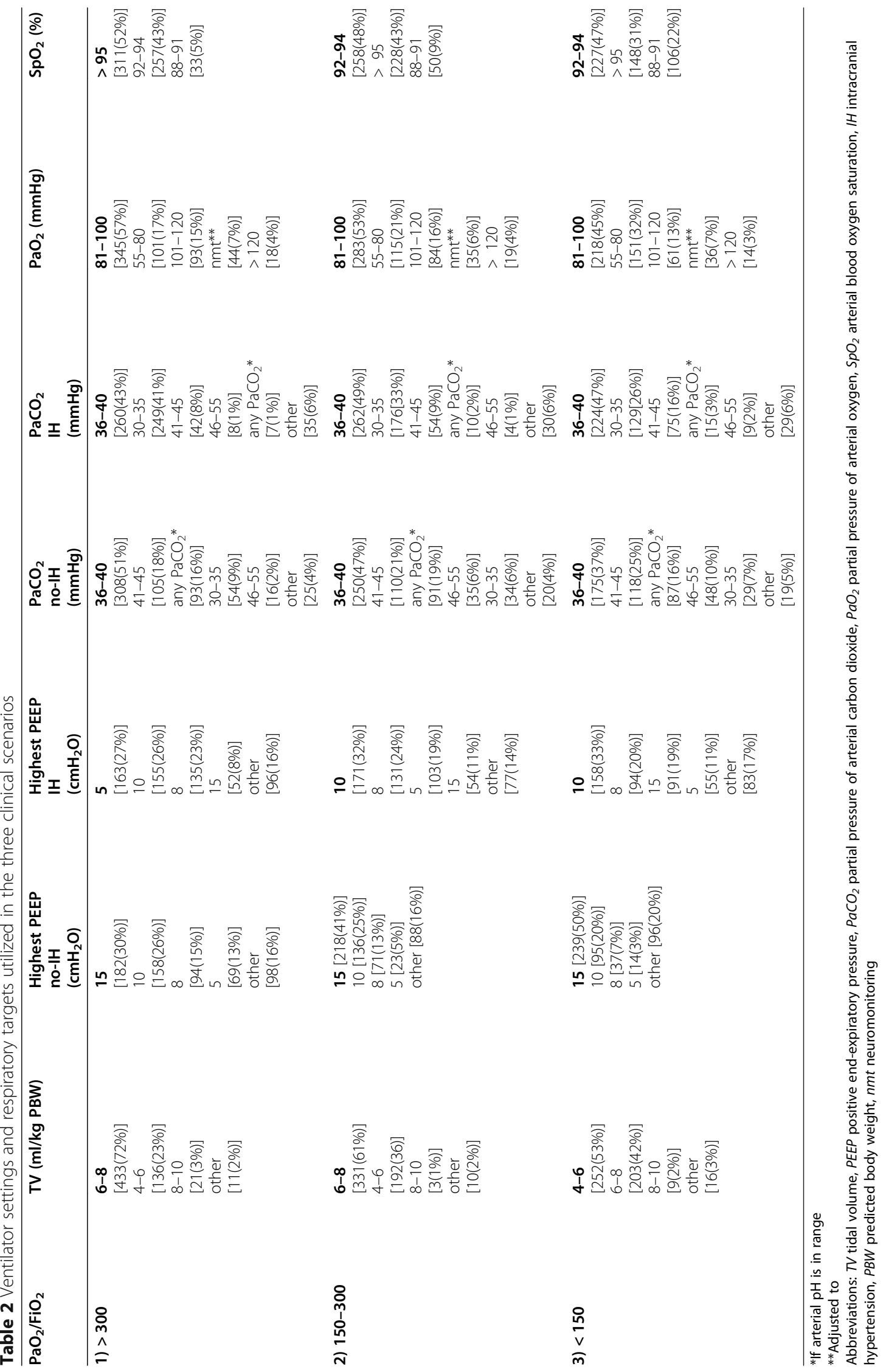




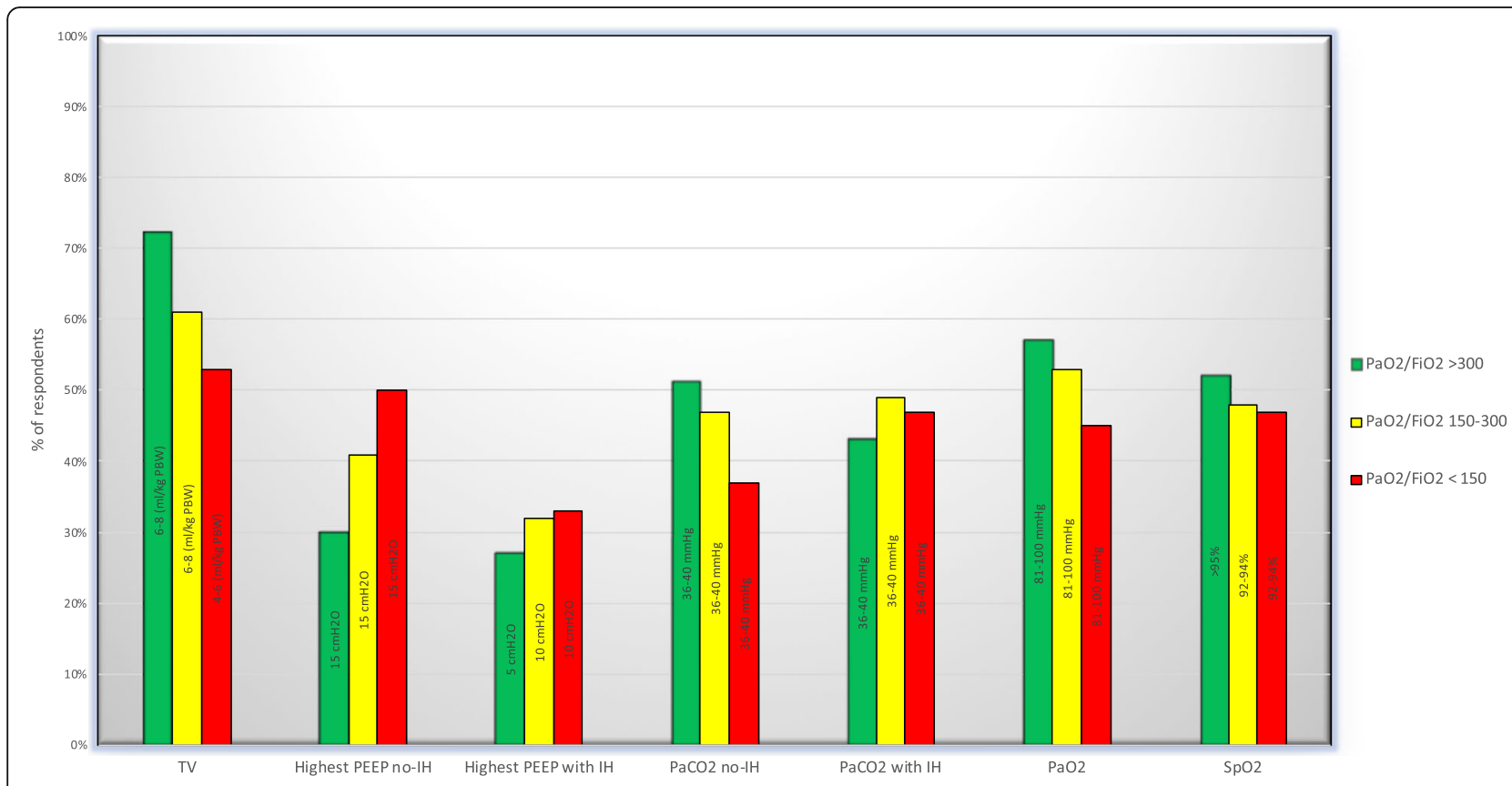

Fig. 2 The commonest ventilator settings and respiratory targets in the three clinical scenarios. Abbreviations: TV = tidal volume, PBW $=$ predicted body weight, $\mathrm{PEEP}=$ positive end-expiratory pressure, $\mathrm{IH}=$ intracranial hypertension, $\mathrm{PaCO}_{2}=$ arterial partial pressure of carbon dioxide, $\mathrm{PaO} \mathrm{O}_{2}=$ arterial partial pressure of oxygen, $\mathrm{SpO}_{2}=$ arterial blood oxygen saturation, $\mathrm{FiO}_{2}=$ inspired oxygen fraction

effects of PEEP on ICP. However, surprisingly, our results show that physicians are keen to use quite high PEEPs (up to 15 in patients with $\mathrm{PaO}_{2} / \mathrm{FiO}_{2}>300$ ) in patients without intracranial hypertension, which is in contrast with growing evidence challenging the utility of "open lung approach" [20]. Probably, the availability of adequate neuro and cardiorespiratory monitoring tools could be useful in setting the right level of PEEP, but more prospective randomized studies are needed to identify the correct level of PEEP in head-injured patients.

Data from our survey show that hyperventilation is not often utilized in TBI patients. This is probably

Table 3 Rescue strategies utilized in case of refractory respiratory failure

\begin{tabular}{ll}
\hline Type of rescue strategy & Respondents $(n=464)$ \\
\hline - NMBAs & $406(88 \%)$ \\
- Recruitment manoeuvres & $319(69 \%)$ \\
- Prone position & $292(63 \%)$ \\
- Bronchoscopy & $239(52 \%)$ \\
- V-V ECMO & $220(47 \%)$ \\
- NO & $115(25 \%)$ \\
- Extracorporeal $\mathrm{CO}_{2}$ removal (DECAP®) & $39(8 \%)$ \\
- Prostacycline & $38(8 \%)$
\end{tabular}

Abbreviations: NMBAs neuromuscular blocking agents, $V-V E C M O$ veno-venous extracorporeal membrane oxygenation, $\mathrm{NO}$ nitric oxide, $\mathrm{CO}_{2}$ carbon dioxide related to the potential ischemic side effects of hypocapnia on the injured brain [21]. Currently, hyperventilation is suggested only in case of emergency with lifethreatening risk of cerebral herniation [22]. However, recent findings suggested that mild, short-term hyperventilation is able to reduce ICP, without a clinically significant reduction of cerebral oxygenation and metabolism [23]. In fact, most responders aimed to a target of $36-40 \mathrm{mmHg}$ of $\mathrm{CO}_{2}$, and only a minority accept mild hypercapnia, even in the absence of intracranial hypertension.

Regarding $\mathrm{PaO}_{2}$ level, the majority of respondents chose a target of $81-100 \mathrm{mmHg}$, greater than those used in ARDS patients $(55-80 \mathrm{mmHg}$ ) and just a minority of respondents accept mild hypoxemia, especially in nonspecialized NICU centres [12]. This choice could be linked to the concern of hypoxia and its detrimental effects on brain-injured patients, but, on the other hand, to the recent evidence regarding the risk related to hyperoxia on critically ill patients [24-27].

\section{Rescue strategies for refractory respiratory failure}

In case of refractory respiratory failure, several rescue manoeuvres are generally employed as adjunct to invasive mechanical ventilation to ameliorate gas exchange. NMBAs have been utilized in ARDS patients to improve gas exchange with inconclusive effects on mortality [28, 29]. Neuromuscular blockade is the most frequently used rescue strategy by our 
respondents; this can be related to their possible beneficial effect also on intracranial hypertension [30, 31]. However, the utilization of NMBAs should take into account their side effects (such as muscle weakness) and should be reserved to the most severe cases [30].

Recruitment manoeuvres can reduce atelectasis and increase lung expiratory lung volumes with potential benefit on gas exchange and lung injury [32]. However, their use has been recently questioned by a recent study showing an increase in mortality in ARDS patients undergoing lung recruitment manoeuvres and titrated PEEP (to the best respiratory system compliance) vs. low PEEP [33]. Recruitment manoeuvres can have potential side effects on the injured brain causing increased intrathoracic pressure similar to the application of high level of PEEP [34]. Despite these effects, they represent the second most utilized rescue strategy in our survey. Data are lacking about the optimal recruitment strategy in TBI patients with ARDS but in this context the use of neuromonitoring (i.e. ICP) seems to be mandatory to optimize systemic oxygenation without causing side effects.

Prone position is frequently utilized in ARDS patients because of its ability to improve ventilation/perfusion ratio, to increase end-expiratory lung volume and to decrease VILI by ameliorating the distribution of the TV [32]. This manoeuvre is able to ameliorate mortality in ARDS only if applied for more than 12 $\mathrm{h} /$ day and in patients with a $\mathrm{PaO}_{2} / \mathrm{FiO}_{2}<150$ [32]. Small studies have been published so far involving patients with neurological damage; in this situation, despite an improvement in systemic/brain oxygenation, an increase in ICP has been often observed [35-39]. As consequence, patients with brain injury have been generally excluded from the only available trial on prone position on ARDS patients [13].

Recently, extracorporeal membrane oxygenation (ECMO) has been utilized as a rescue strategy in ARDS patients $[39,40]$. Historically, ECMO was not utilized in TBI patients because of the risk of cerebral bleeding related to the use of anticoagulation. Recently, some case reports and small case series have suggested a potential beneficial use of ECMO in TBI patients [41]. Surprisingly, nearly half of our respondents would use ECMO in TBI patients as rescue respiratory strategy. This could be related to the possibility to adopt heparin-free venovenous (VV) ECMO with consequent less risk of bleeding complications [42, 43]. However, the role of ECMO in TBI patients with refractory respiratory therapy requires further investigations.

Finally, only a small amount of our respondents suggested the use of extracorporeal $\mathrm{CO}_{2}$ removal (i.e. DECAP $^{\circ}$ ) in TBI patients; although a small dose of heparin is necessary for this method with low risk of bleeding, the efficacy of $\mathrm{CO}_{2}$ extracorporeal $\mathrm{CO}_{2}$ removal is limited and rarely used in the clinical practice [44].

Ventilatory strategies in trauma patients could take into account the phase of treatment and the underlying injuries [45].

\section{Limitations}

As with all methods of data collection, survey research also comes with a few drawbacks as inflexibility and validity. This survey presents also other limitations. First, the response rate cannot be calculated considering the design of this survey; in fact, ESICM members are invited to involve more participants locally, thus making impossible to obtain the total number of people who received the survey. Second, respondents from specialized NICUs were included together with those working in general ICUs. This might be considered a methodological limitation but, as TBI patients are treated worldwide not only in specialized NICUs, we believe that our approach produced more generalizable findings. Third, this survey was developed by two investigators without a prior systematic review of the literature or pilot testing in a smaller sample of participants; this might further limit the quality of the questionnaire and data. Fourth, this survey refers only to physicians' clinical practice in respiratory management of TBI without including patients' data.

\section{Conclusions}

In conclusion, this survey shows that important differences in the clinical practice in the ventilatory management of TBI patients with and without respiratory failure still exist. Lung-protective ventilation strategies seem to be more frequently applied in the clinical practice in brain-injured patients, although most respondents still seem to have concerns regarding the use of high PEEP in case of intracranial hypertension. Future studies are warranted to clarify the huge practice variability among centres.

\section{Supplementary information}

Supplementary information accompanies this paper at (https://doi.org/10. 1186/s13054-020-02875-w).

Additional file 1. Appendix 1, Table S1, Table S2, - Table S3. (DOCX 40 kb)

\section{Abbreviations}

TBI: Traumatic brain injury; ARDS: Acute respiratory distress syndrome; $\mathrm{PaO}_{2}$ : Arterial partial pressure of oxygen; $\mathrm{FiO}_{2}$ : Inspired fraction of oxygen; ESICM: European Society of Intensive Care Medicine; PBW: Predicted body weight; PEEP: Positive end-expiratory pressure; ICU: Intensive care unit; TV: Tidal volume; $\mathrm{CO}_{2}$ : Carbon dioxide; NICU: Neuro-ICU; $\mathrm{PaCO}_{2}$ : Arterial partial pressure of $\mathrm{CO}_{2}$; NMBAs: Neuromuscular blocking agent: ICP: Intracranial pressure; CPP: Cerebral perfusion pressure; CBF: Cerebral 
blood flow; ECMO: Extracorporeal membrane oxygenation; W: Veno-venous; NIRS: Near-infrared spectroscopy

\section{Acknowledgements}

We would like to acknowledge the support of ESICM and all the participants to the survey.

\section{Funding}

None.

\section{Availability of data and materials}

The datasets used and/or analysed during the current study are available from the corresponding author on reasonable request.

\section{Authors' contributions}

E.P. and C.R. were involved in the study design, acquisition of data, analysis and interpretation of data, drafting of the manuscript and critical revision. P.P. and G.C. were involved in the study design, analysis and interpretation of data, drafting of manuscript and critical revision. F.S.T. and J.M. were involved in the study design, drafting of the manuscript and critical revision. All authors read and approved the final manuscript.

\section{Ethics approval and consent to participate} Not applicable.

\section{Consent for publication}

Not applicable.

\section{Competing interests}

The authors declare that they have no competing interests.

\section{Author details}

'Department of Anesthesia and Intensive Care, Parma University Hospital, Via Gramsci 14, 43100 Parma, Italy. ${ }^{2}$ Department of Anesthesia and Intensive Care, IRCCS for Oncology and Neurosciences, Genoa, Italy. ${ }^{3}$ Department of Surgical Sciences and Integrated Diagnostics, University of Genoa, Genoa, Italy. ${ }^{4}$ Department of Intensive Care, Erasme Hospital, Université Libre de Bruxelles (ULB), Brussels, Belgium. ${ }^{5}$ School of Medicine and Surgery, University of Milan - Bicocca, Monza, Italy. ${ }^{6}$ Department of Intensive Care, Sant Pau Hospital, Barcelona, Spain.

\section{Received: 3 January 2020 Accepted: 6 April 2020}

\section{Published online: 17 April 2020}

\section{References}

1. Maas AIR, Menon DK, Adelson PD, Andelic N, Bell MJ, Belli A, et al. Traumatic brain injury: integrated approaches to improve prevention, clinical care, and research. Lancet Neurol. 2017;16(12):987-1048.

2. Asehnoune K, Roquilly A, Cinotti R. Respiratory Management in Patients with severe brain injury. Crit Care. 2018;22(1):76.

3. Piek J, Chesnut RM, Marshall LF, van Berkum-Clark M, Klauber MR, Blunt BA et al. Extracranial complications of severe head injury. J Neurosurg. 1992; 77(6):901-7.

4. Rincon F, Ghosh S, Dey S, Maltenfort M, Vibbert M, Urtecho J, et al. Impact of acute lung injury and acute respiratory distress syndrome after traumatic brain injury in the United States. Neurosurgery. 2012;71(4):795-803.

5. Pelosi P, Ferguson ND, Frutos-Vivar F, Anzueto A, Putensen C, Raymondos K et al. Management and outcome of mechanically ventilated neurologic patients. Crit Care Med. 2011;39(6):1482-92.

6. Serpa Neto A, Hemmes SN, Barbas CS, Beiderlinden M, Biehl M, Binnekade $J M$, et al. Protective versus conventional ventilation for surgery: a systematic review and individual patient data meta-analysis. Anesthesiology. 2015; 123(1):66-78.

7. Fan E, Brodie D, Slutsky AS. Acute respiratory distress syndrome: advances in diagnosis and treatment. JAMA. 2018;319(7):698-710.

8. Slutsky AS, Ranieri VM. Ventilator-induced lung injury. N Engl J Med. 2013; 369(22):2126-36

9. Oddo M Citerio G. ARDS in the brain-injured patient: what's different? Intensive Care Med. 2016;42(5):790-3.
10. Frisvold SK, Robba C, Guérin C. What respiratory targets should be recommended in patients with brain injury and respiratory failure? Intensive Care Med. 2019;45(5):683-6.

11. Mascia L, Zavala E, Bosma K, Pasero D, Decaroli D, Andrews P, et al. High tidal volume is associated with the development of acute lung injury after severe brain injury: an international observational study. Crit Care Med. 2007;35(8):1815-20.

12. The Acute Respiratory Distress Syndrome Network. Ventilation with lower tidal volumes as compared with traditional tidal volumes for acute lung injury and the acute respiratory distress syndrome. N Engl J Med. 2000; 342(18):1301-8

13. Guérin C, Reignier J, Richard JC, Beuret P, Gacouin A, Boulain T, et al. Prone positioning in severe acute respiratory distress syndrome. N Engl J Med. 2013;368(23):2159-68.

14. Borsellino B, Schultz MJ, Gama de Abreu M, Robba C, Bilotta F. Mechanical ventilation in neurocritical care patients: a systematic literature review Expert Rev Respir Med. 2016;10(10):1123-32.

15. Della Torre V, Badenes R, Corradi F, Racca F, Lavinio A, Matta B, et al. Acute respiratory distress syndrome in traumatic brain injury: how do we manage it? J Thorac Dis. 2017;9(12):5368-81.

16. Muench $E_{\text {, Bauhuf }}$, Roth $H_{1}$, Horn P, Phillips M, Marquetant N, et al. Effects of positive end-expiratory pressure on regional cerebral blood flow, intracranial pressure, and brain tissue oxygenation. Crit Care Med. 2005; 33(10):2367-72

17. Caricato A, Conti G, Della Corte F, Mancino A, Santilli F, Sandroni C, et al. Effects of PEEP on the intracranial system of patients with head injury and subarachnoid hemorrhage: the role of respiratory system compliance. J Trauma. 2005;58(3):571-6.

18. Mascia L, Grasso S, Fiore T, Bruno F, Berardino M, Ducati A. Cerebropulmonary interactions during the application of low levels of positive endexpiratory pressure. Intensive Care Med. 2005;31(3):373-9.

19. Robba C, Bragazzi NL, Bertuccio A, Cardim D, Donnelly J, Sekhon M, et al. Effects of prone position and positive end-expiratory pressure on noninvasive estimators of ICP: a pilot study. J Neurosurg Anesthesiol. 2017; 29(3):243-50.

20. Pelosi P, Rocco PRM, Gama de Abreu M. Close down the lungs and keep them resting to minimize ventilator-induced lung injury. Crit Care. 2018; 22(1):72.

21. Coles JP, Fryer TD, Coleman MR, Smielewski P, Gupta AK, Minhas PS, et al. Hyperventilation following head injury: effect on ischemic burden and cerebral oxidative metabolism. Crit Care Med. 2007;35(2): 568-78.

22. Carney N, Totten AM, O'Reilly C, UIlman JS, Hawryluk GW, Bell MJ, et al. Guidelines for the Management of Severe Traumatic Brain Injury, Fourth Edition. Neurosurgery. 2017:80(1):6-15.

23. Brandi G, Stocchetti N, Pagnamenta A, Stretti F, Steiger P, Klinzing S. Cerebral metabolism is not affected by moderate hyperventilation in patients with traumatic brain injury. Crit Care. 2019;23(1):45.

24. Davis DP, Meade W, Sise MJ, Kennedy F, Simon F, Tominaga G, et al. Both hypoxemia and extreme hyperoxemia may be detrimental in patients with severe traumatic brain injury. J Neurotrauma. 2009;26(12):2217-23.

25. Brenner M, Stein D, Hu P, Kufera J, Wooford M, Scalea T. Association between early hyperoxia and worse outcomes after traumatic brain injury. Arch Surg. 2012;147(11):1042-6.

26. Rincon F, Kang J, Vibbert M, Urtecho J, Athar MK, Jallo J. Significance of arterial hyperoxia and relationship with case fatality in traumatic brain injury: a multicentre cohort study. J Neurol Neurosurg Psychiatry. 2014:85(7):799-805

27. Quintard H, Patet C, Suys T, Marques-Vidal P, Oddo M. Normobaric hyperoxia is associated with increased cerebral excitotoxicity after severe traumatic brain injury. Neurocrit Care. 2015;22(2):243-50.

28. Papazian L, Forel JM, Gacouin A, Penot-Ragon C, Perrin G, Loundou A, et al. Neuromuscular blockers in early acute respiratory distress syndrome. N Engl J Med. 2010;363(12):1107-16.

29. National Heart, Lung, and Blood Institute PETAL Clinical Trials Network. Early neuromuscular blockade in the acute respiratory distress syndrome. $\mathrm{N}$ Engl Jed. 2019;380(21):1997-2008

30. deBacker J, Hart N, Fan E. Neuromuscular blockade in the 21st century Management of the Critically ill Patient. Chest. 2017;151(3):697-706.

31. Hawryluk GWJ, Aguilera S, Buki A, Bulger E, Citerio G, Cooper DJ, et al. A management algorithm for patients with intracranial pressure monitoring: 
the Seattle international severe traumatic brain injury consensus conference (SIBICC). Intensive Care Med. 2019;45(12):1783-94.

32. Fan E, Del Sorbo L, Goligher EC, Hodgson CL, Munshi L, Walkey AJ, et al. American Thoracic Society, European Society of Intensive Care Medicine, and Society of Critical Care Medicine. An official American Thoracic Society/ European Society of Intensive Care Medicine/Society of Critical Care Medicine clinical practice guideline: mechanical ventilation in adult patients with acute respiratory distress syndrome. Am J Respir Crit Care Med. 2017; 195(9):1253-63.

33. Cavalcanti AB, Suzumura ÉA, Laranjeira LN, Paisani DM, Damiani LP, Guimarães HP, et al. Effect of lung recruitment and titrated positive endexpiratory pressure (PEEP) vs low PEEP on mortality in patients with acute respiratory distress syndrome: a randomized clinical trial. JAMA. 2017; 318(14):1335-45.

34. Bein T, Kuhr LP, Bele S, Ploner F, Keyl C, Taeger K. Lung recruitment maneuver in patients with cerebral injury: effects on intracranial pressure and cerebral metabolism. Intensive Care Med. 2002;28(5):554-8.

35. Beuret P, Carton MJ, Nourdine K, Kaaki M, Tramoni G, Ducreux JC. Prone position as prevention of lung injury in comatose patients: a prospective, randomized, controlled study. Intensive Care Med. 2002;28(5):564-9.

36. Reinprecht A, Greher M, Wolfsberger S, Dietrich W, Illievich UM, Gruber A. Prone position in subarachnoid hemorrhage patients with acute respiratory distress syndrome: effects on cerebral tissue oxygenation and intracranial pressure. Crit Care Med. 2003:31(6):1831-8

37. Thelandersson A, Cider A, Nellgård B. Prone position in mechanically ventilated patients with reduced intracranial compliance. Acta Anaesthesiol Scand. 2006;50(8):937-41

38. Nekludov M, Bellander BM, Mure M. Oxygenation and cerebral perfusion pressure improved in the prone position. Acta Anaesthesiol Scand. 2006; 50(8):932-6.

39. Peek GJ, Mugford M, Tiruvoipati R, Wilson A, Allen E, Thalanany MM, et al. Efficacy and economic assessment of conventional ventilatory support versus extracorporeal membrane oxygenation for severe adult respiratory failure (CESAR): a multicentre randomised controlled trial. Lancet. 2009; 374(9698):1351-63.

40. Combes A, Hajage D, Capellier G, Demoule A, Lavoué S, Guervilly C, et al. Extracorporeal membrane oxygenation for severe acute respiratory distress syndrome. N Engl J Med. 2018;378(21):1965-75.

41. Robba C, Ortu A, Bilotta F, Lombardo A, Sekhon MS, Gallo F, et al. Extracorporeal membrane oxygenation for adult respiratory distress syndrome in trauma patients: a case series and systematic literature review. J Trauma Acute Care Surg. 2017:82(1):165-73.

42. Muellenbach RM, Kredel M, Kunze E, Kranke P, Kuestermann J, Brack A, et al. Prolonged heparin-free extracorporeal membrane oxygenation in multiple injured acute respiratory distress syndrome patients with traumatic brain injury. J Trauma Acute Care Surg. 2012;72(5):1444-7.

43. Della Torre V, Robba C, Pelosi P, Bilotta F. Extra corporeal membrane oxygenation in the critical trauma patient. Curr Opin Anaesthesiol. 2019; 32(2):234-41.

44. Combes A, Fanelli V, Pham T, Ranieri VM, European Society of Intensive Care Medicine Trials Group and the "strategy of ultra-protective lung ventilation with extracorporeal $\mathrm{CO} 2$ removal for new-onset moderate to severe ARDS" (SUPERNOVA) investigators. Feasibility and safety of extracorporeal CO(2) removal to enhance protective ventilation in acute respiratory distress syndrome: the SUPERNOVA study. Intensive Care Med. 2019;45(5):592-600.

45. Hardcastle TC, Muckart DJ, Maier RV. Ventilation in trauma patients: the first $24 \mathrm{~h}$ is different! World J Surg. 2017:41(5):1153-8,

\section{Publisher's Note}

Springer Nature remains neutral with regard to jurisdictional claims in published maps and institutional affiliations.

Ready to submit your research? Choose BMC and benefit from:

- fast, convenient online submission

- thorough peer review by experienced researchers in your field

- rapid publication on acceptance

- support for research data, including large and complex data types

- gold Open Access which fosters wider collaboration and increased citations

- maximum visibility for your research: over $100 \mathrm{M}$ website views per year

At BMC, research is always in progress.

Learn more biomedcentral.com/submissions 